\title{
Anthropic expansion of Paraty in Serra da Bocaina National Park, Mata Atlântica Biome
}

\author{
Camila Coelho Welerson \\ Winne Nayadini Barão \\ Brunna Araújo Quireli \\ Vanêssa Lopes de Faria \\ Nivea Adriana Dias Pons \\ Daniela Rocha Teixeira Riondet-Costa \\ Ana Luiza de Souza Marcondes
}

${ }^{1}$ Universidade Federal de Itajubá, Itajubá, Minas Gerais, Brasil.

"Iniversidade Federal de Itajubá, Itajubá, Minas Gerais, Brasil.

D III Universidade Federal de Itajubá, Itajubá, Minas Gerais, Brasil.

(D) ${ }^{I V}$ Universidade Federal de Lavras, Lavras, Minas Gerais, Brasil.

D ${ }^{\mathrm{V}}$ Universidade Federal de Itajubá, Itajubá, Minas Gerais, Brasil.

(D) ${ }^{\mathrm{V}}$ Universidade Federal de Itajubá, Itajubá, Minas Gerais, Brasil.

D VII Universidade Federal de Itajubá, Itajubá, Minas Gerais, Brasil.
Abstract: This paper analyzed the anthropic expansion of the municipality of Paraty-RJ in relation to the Serra da Bocaina National Park. In addition to the bibliographic and documentary revision of the Municipal Master Plan and the Park Management Plan, geoprocessing tools were used for chronological analyzes of land use and occupation change in 2001, 2006 and 2018, using images from the satellite Landsat 5 and Landsat 8. It was verified the growth of the anthropic occupation in a diffuse way in relation to the Park, without respect to the municipal planning, reflecting in the decrease of the native vegetation cover. Both the Master and Management Plans have been inefficient in terms of their objectives, justifying the need for improvements in Paraty and Park management through the responsible agencies.

Keywords: Protected área; land use; geoprocessing; irregular occupation; environmental management.

São Paulo. Vol. 24, 2021

Original Article

DOI: http://dx.doi.org/10.1590/1809-4422asoc20200023r1vu2021L2AO 


\section{Introduction}

Much is discussed about the negative influence of anthropic action in the modification of urban and natural spaces (SILVA et al., 2018; SANTOS; PACHECO, 2017; MELO et al., 2016). Land use and occupation are significantly altered as the urban population grows, often reducing green areas and collaborating with deforestation (OLIVEIRA; LIMA; SOUSA, 2017; SILVA; SILVA; SILVA, 2016). In this context, Barbosa, Oliveira, and Ribeiro (2016) and Kain et al. (2016) stress the need for effective planning of land use, so that activities and functions of urban environments could coexist with natural environments in a rational and integrated manner.

In view of the importance and the concerns about this thematic, the Constitution of the Federative Republic of Brazil of 1988 (FC) expressly foresaw, in its Art. 182, paragraph $1^{\circ}$, the regulation of municipal policies to guide urban expansion through a Master Plan (BRASIL, 1988). Therefore, considering the need for this regulation, in 2001, Law №. 10.257 (City Statute) was enacted, making the plan mandatory for cities with more than 20 thousand inhabitants, metropolitan regions and urban agglomerations, cities within areas of special tourist interest, cities that have, in their territorial limits, enterprises or activities with significant regional or national environmental impact (BRASIL, 2001), and cities with susceptibility to high-impact landslides, flash floods, or corresponding geological and hydrological processes (BRASIL, 2012).

In the art. 225 of the FC, it is established everyone's right to an ecologically balanced environment and obligates Public Authorities to preserve and restore essential ecological processes, as well as the determination of territorial areas, which should be protected, to preserve biodiversity from practices that could jeopardize its ecological functions, cause species extinction, or expose animals to cruelty (BRASIL, 1988).

The National System of Nature Conservation Units (SNUC, Law 9.985/2000), which regulated the $\S 1 \mathrm{O}$ of art. 225 of the FC, is composed of the set of federal, state, and municipal conservation units that are intended, among other objectives, to contribute to the preservation and restoration of biodiversity in natural ecosystems, along with the promotion of sustainable development. Among the definitions covered in Law 9.985, the Art. 2, item XVII, specifically addresses the Management Plan, a technical document that establishes the environmental zoning in protected areas and the rules that govern their use and management, including the demarcation of buffer zones (BZ) (BRASIL, 2002; BRASIL, 2006).

It was established by the SNUC that the specific objectives of each area should be defined according to the type of protection and permitted uses (BRASIL, 2000), falling into two categories: sustainable use and full protection. National Parks are included in the last category, which, according to Sousa and Santos (2016), consist of areas where scientific research and didactic activities must be previously authorized by the responsible agency and whose public visitation and tourism are subjected to rules and restrictions expressed in the Management Plan. Concerning these mentioned authorizations, they are predicted in the ICMBio Normative Instruction No. 03/2014, which regulates the 
remote system for research assistance (ICMBIO, 2014).

A great advance is perceived over the last decades concerning the expansion of environmental laws, aiming to guarantee a sustainable environment. Even though legal provisions safeguard natural environment preservation when it borders urban environments, several conflicts between Protected Areas (PAs) and anthropic expansion have been portrayed.

Gray et al. (2016) explored the issue of the significant growth of anthropic pressures over PAs in Latin America, Africa, and Asia, which was corroborated by Watson et al. (2015) and Bernard, Penna, and Araújo (2014). The first authors researched PAs in Zambia, Africa, concluding that anthropic actions, such as deforestation and encroachment, could transform these areas into small, isolated clusters, threatening local carnivore species (WATSON et al., 2015). The second study strictly deals with national parks and reserves, inferring that between 1981 and 2012 there were 93 events related to area reduction and degradation, mainly in the Amazon region (BERNARD; PENNA; ARAÚJO, 2014). Still, these events may have been motivated by financial resource shortages and lack of trained staff within the management agencies, coupled with inefficient surveillance and the morosity of the Brazilian justice system to punish offenders, compromising the effectiveness and challenging the integrity of the management (BERNARD; PENNA; ARAÚJO, 2014). Complementary to these studies, Brito (2008) and Matheus Silva (2017) introduced the conflicts between local communities and the management and maintenance of PAs, which are characterized, to the present day, by intense and complex relationships.

Ruiz Junior and De Oliveira (2013) showed the conflicting relationship between the PAs and the disorderly growth in the northern coast of São Paulo by mapping such areas, evidencing irregular appropriation of spaces governed by public policies. For Marandola Junior, De Paula, and Cassaneli (2013), the policies for urban development are not only linked to population growth, leading to the occupation of protected areas but rather to exclusion and segregation processes derived from city development, such as road axes expansions oriented to tourism and the growth of service structures in the northern coast of São Paulo. Egler, De Gusmão, and Santos (2013) stress that the implementation of logistics projects in the southeastern coast does not always foresee the territorial capacity in terms of infrastructure and may not be adequate to local policies, possibly not listing the social and environmental dimensions of involved municipalities. For the authors, there is a delayed response of local governments about the formulation of strategic public policies for territorial development, not meeting the existing demands and exerting pressure on spaces protected by law.

Real estate speculation in the municipalities of Paraty (RJ) and Ubatuba (SP) began in the 1960s (ABIRACHED, 2011), forcing traditional communities and immigrant workers to move to the periphery, occupying spaces that would become the PA, restricting land use in these territories, and creating conflicts between population and governments. According to the author, new demands for occupation have grown due to the "expansion of ports, installation of the Pre-Salt, expansion of the Rio-Santos highway stretches, and 
construction of the Angra III nuclear power plant" (p. 40).

Furthermore, Hansen and DeFries (2007) draw attention to an issue that was, in fact, the basis for the creation of BZs by the SNUC: the impact that changes in the use and occupation of areas around Parks may have on their biodiversity, which can be threatened even if the areas of the Park itself were completely preserved. This issue was also raised in the studies by Koch (2016) and Rudke et al. (2013), who conducted temporal analyses on changes in the land use and cover in BZs, concluding that local ecosystems may have been significantly affected by anthropic activities carried out by landowners within these sites.

Fontes and Guerra (2016) and Garcia et al. (2014), in turn, conducted even deeper analyses, questioning the effectiveness of PAs Management Plans, indicating that part of the conflicts may have resulted from various overlapping management instruments, juxtaposing norms and rules; and from the rigidity of the SNUC, hindering the culture protection of these populations residing in full protected areas. This divergence in the management instruments is also presented by Figueiroa and Scherer (2016), who addressed the lack of consonance between the Master and Management Plans, with attention to cases in which municipal planning is in disagreement with the current environmental legislation.

Concerning the SNUC rigidity, one should also take into consideration what was presented by Cumming et al. (2015) for the resilience of PAs in face of population growth in their surroundings. The authors infer that PAs can no longer behave as ecological islands isolated from the neighboring socio-economic system, and should; therefore, be able to adapt to changes over time and support local communities and ecosystems of conservation interest; to promote socio-ecological resilience within units. Another impasse, portrayed by Coad et al. (2015), is related to budget limitations and lack of investments in training programs for managers. Thus, these authors conclude that, in the absence of funds and effective policies, it is unlikely that investments will be made for consistent scientific data production to be used for impact monitoring, even though the update of such data is essential for the PA management. Geldmann et al. (2015) further discourse about management quality, which for most PAs is unknown, and on how much improvement could be brought by well-directed conservation projects.

In light of the above mentioned, the present work sought to analyze the process of anthropic expansion of the municipality of Paraty (Rio de Janeiro) concerning the Serra da Bocaina National Park (PNSB), in the Atlantic Forest Biome, and their respective Master and Management Plans, since the creation of the SNUC to the present day.

\section{Methods}

Area of Study

Created by the Federal Decree no ${ }^{\mathrm{o}}$ 68.172/1971, the Serra da Bocaina National Park is located between the geographic coordinates $22^{\circ} 40^{\prime}$ and $23^{\circ} 20^{\prime} \mathrm{S}$ and $44^{\circ} 24^{\prime}$ and 
445' W, within the border of Rio de Janeiro and São Paulo States (BRASIL, 1971; ICMBIO, 2001). According to Novaes et al. (2005), 60\% of the park is in Rio de Janeiro (municipalities of Angra dos Reis - 21.6\% and Paraty - 40.3\%), while $\sim 40 \%$ is in São Paulo (São José do Barreiro - 18.3\%, Ubatuba - 12.7\%, Cunha - 4.5\%, and Areias - 2.4\%).

Currently, the PA has 104 thousand hectares of Atlantic Forest biome, one of the ecosystems with the richest plant and animal species diversity and endemism in the world, with approximately 321 mammal species, 89 of which are endemic (PAGLIA et al. 2012; PINTO et al. 2012; SILVA, 2017). Moreover, it is among the world's 25 hotspots with the highest concentration of endangered species (MYERS et al., 2000; KLINK; MACHADO, 2005; SILVA, 2017; FREITAS et al., 2019).

The PNSB Management Plan was approved 31 years after its creation, by the Ibama Decree 112/2002 (ICMBIO, 2002). This document establishes the zoning of the Park, rules that guide the use and management of natural resources; the buffer zone; and implement the physical structures of the management. The environmental zoning was initially oriented toward the identification of a core, that reflected the most conserved characteristics of the PA, and then, strategic areas were defined aiming to maximize natural resources preservation.

This management was defined based on twelve specific objectives. Among them, protection to springs and maintenance of natural landscapes, besides allowing scientific research, leisure, and ecotourism, providing integration between visitors and park management, thereby ensuring understanding and appreciation for environmental conservation (ICMBio, 2002).

Along with park area demarcations, the buffer zone was also defined, pursuing the minimization of negative impacts over protected areas. This buffer zone, in brief, corresponds to an area around the Park, where anthropic actions are subject to specific rules and restrictions, according to the Management Plan of the protected area (BRASIL, 2000).

Thus, since Paraty encompasses more than $40 \%$ of the PNSB area and is fully included in its buffer zone, this municipality was selected for the anthropogenic expansion analysis. The municipality is located in an area of 925.39 square kilometers, at an altitude of 5 meters, in which tourism is one of the main regional economic activities (CLIMATE-DATA, 2018; IBGE, 2010).

\section{Data acquisition and treatment}

It was performed bibliographic and documentary research for the analysis of the municipal Master Plan and the Park Management Plan, which included a search for documents, norms, legislation, and secondary data associated with the studied areas and their relationship with land use and occupation. In this step, searches were made in databases of the Legislation Portal, National Institute for Space Research (INPE), Brazilian Institute of Geography and Statistics (IBGE), and Chico Mendes Institute for Biodiversity Conservation (ICMBio). 
For the anthropic expansion analysis of the municipality of Paraty/RJ concerning the PNSB, it was chosen geoprocessing tools to generate maps of land use and occupation for three periods: 2001, one year after the creation of the SNUC; 2006, the year before the enactment of the Paraty Master Plan; and 2018, the initial year of this study. These maps were superimposed to identify changes that occurred within this period.

The choice for geoprocessing was made based on the works of Silva (2010) and Jacintho (2003), which used these tools for chronological analyses of changes in land use and occupation. The first author analyzed the implications of the land use and land cover evolution in the municipality of Paraty/RJ from 1973 to 2008, and the second author used geoprocessing and remote sensing for environmental management of protected areas. Both concluded that the use of these tools produced satisfactory results, and also contributed to the production of consistent databases, which can be used by managing agencies. Use and occupation maps can serve as a basis for formulation of public policies on urban planning and forest conservation, including research and management activities in these areas (MAS et al., 2017; GOUNARIDIS; APOSTOLOU; KOUKOULAS, 2016).

After compiling the data found, a step of image selection was started to elaborate maps for anthropic expansion analyses. Two images from Landsat 5 and one from Landsat 8 satellites, available from the National Institute for Space Research (INPE) platform were chosen for this purpose. The use of these satellite products is an effective way to obtain accurate and timely information on the spatial distribution of land cover and site characteristics, allowing efficient monitoring of landscapes, which are crucial for natural resources conservation (GOUNARIDIS et al., 2016; WILLIS, 2015).

It was adopted for image processing supervised classification, based on the works of Vale et al. (2018), Prates et al. (2017), and Camilo Silva et al. (2017). In this procedure, images were imported into the Geographic Information System (GIS) QGIS, version 2.18.10 and preprocessed, forming an RGB color composition with the bands 5, 4, and 3 for the Landsat 5 images, and with the bands 4, 3, and 2 for the Landsat 8 image, all of them with a spatial resolution of 30 meters. Subsequently, 10 training samples were selected to identify the attributes of each defined uses and occupation classes: forest formation, constructed area, river, lake and ocean, pasture and exposed soil, ground-vegetation, and shade. It is important to emphasize that the shadow type classification was incorporated into the forest formation classification, since comparing the generated images with satellite images from Google Earth Pro version 7.3, it was concluded that these shadows were formed by treetops due to the timing at which the images were obtained by the satellites.

Finally, using the Semi-Automatic Classification Plugin of the same software, images were classified, resulting in land use and land cover maps for each year. Next, an analysis of anthropic expansion was performed, which was associated with the increase in areas corresponding to the classes: constructed area, pasture, and exposed soil. Then, the anthropic expansion advance over the PNSB was confronted with information from the Master Plan of Paraty and from the directives of the Management Plan of the PA, regarding expansion, urban occupation, and anthropic activities. 


\section{Results and Discussion}

The municipality of Paraty is organized by an Organic Law established in 1990, which must follow all changes that may occur within the limits of Paraty, always being updated to fulfill all community's rights and demands (RIO DE JANEIRO, 1990). As a complement to this law and in conformity with the required creation of an Integrated Development Master Plan for the municipality of Paraty, it was enacted the Complementary Law 034/2007 (RIO DE JANEIRO, 2007). A Master Plan is mandatory for this municipality since it is a touristic area and has a population of 37,533 inhabitants (IBGE, 2010).

Concerning urban expansion, the Organic Law of Paraty instituted, in its Art. 178, $\S 1$, obedience to the directives expressed in the Master Plan, which is also the basic instrument for development policy (RIO DE JANEIRO, 1990), responsible for organizing land use and occupation in consonance with the social function of property and with the preservation of both natural and constructed environments, a directive included in its Art. 8, item V (RIO DE JANEIRO, 2007).

The Municipal Macrozoning map of Paraty was elaborated, where areas of urban and rural occupation are delimited, including areas of National and State Parks, Environmental Protection Areas (APA), and Ecological Reserves, along with areas of urban expansion for tourism purposes. These are composed of a strip of land between the sea and an elevation line of two hundred meters toward inland, following the BR-101 highway along the coast, as specified in Art. 208 of the Master Plan of Paraty. It is important to emphasize that, according to the stated in this Master Plan and in the Municipal Macrozoning Map, the intention is that urban occupation expands up to the limits of the PNSB, which is contrary to the established by the SNUC. Concerning PAs, Art. 203 states that respecting federal and state regulations that are applied to these areas, the municipality of Paraty may supplementary legislate on the use and occupation of these units, as long as the agencies responsible for the protected areas were consulted (RIO DE JANEIRO, 2007).

The Master Plan of Paraty also has a specific section on the PNSB. Art. 221 states that within Park areas it will not be allowed any kind of land parceling, use, nor occupation for urban purposes, and any project or enterprise must be submitted for prior appreciation (RIO DE JANEIRO, 2007, p. 48). Furthermore, the same article also states that urban centers located within the limits of the Park will be clearly delimited for urban occupation ends (RIO DE JANEIRO, 2007, p. 48).

It is important to stress that the legislation is still silent about what was foreseen in Art. 165 of Paraty`s Master Plan, which establishes the creation of the Environment and Natural Resources Management Plan, a basic normative instrument for the management of municipal environmental heritage, and which would bring the rules of occupation and use of the PAs (RIO DE JANEIRO, 2007).

Although the Master Plan of Paraty establishes, in its Art. 203, that the dialogue with the environmental agencies about the use and occupation of areas related to the PNSB is of utmost importance (RIO DE JANEIRO, 2007, p. 45), one must have in mind that the Park corresponds to a fully protected PA. In other words, to preserve this 
natural ecosystem of great national relevance, the rules governing the PNSB should be strict, not admitting any kind of human occupation and even promoting expropriation of private areas included within its limits (BRASIL, 2000). However, according to Rocha, Drummond, and Ganem (2010), this does not correspond to the reality, largely due to the difficulty in land property regularization in this region.

According to the PNSB Management Plan itself, the history of land distribution in the municipality of Paraty is marked by several conflicts, mainly due to real estate speculation and the growing interest in building hotels, inns, and restaurants, given the touristic importance of the region (ICMBIO, 2002). This caused the migration of the most disadvantaged population into the forest, and it is estimated that 115 families are residing within PNSB areas (ICMBIO, 2002); however, this number may have increased given the analysis of the generated maps. Moreover, according to ICMBIO (2002), the majority of the population is unaware of the PNSB limits, consequently ignoring its existence. Another conflicting aspect to be considered is the PNSB, a large proportion of municipal area was incorporated in its limits; what was left for agricultural production is a meadow with great runoff problems, which also corresponds to a region of legal protection, since it is localized at sea level (ICMBIO, 2002).

Those conflicts are perceptible when satellite images of the region are analyzed. Although urban occupation areas of the municipality of Paraty have been delimited by the Master Plan, what is noticeable is a significant increase of anthropic expansion over the PNSB, with considerable growth of pasture and constructed areas when comparing land use and land occupation images from 2001, 2006, and 2018 (Figure 1), and can be said that these areas have been expanding irregularly. By analyzing the numbers of such expansion, through data in Table 1, this observation becomes even more evident. 
Figure 1 - Mapping the anthropic expansion of the municipality of Paraty in relation to the PNSB in the years 2001, 2006 and 2018
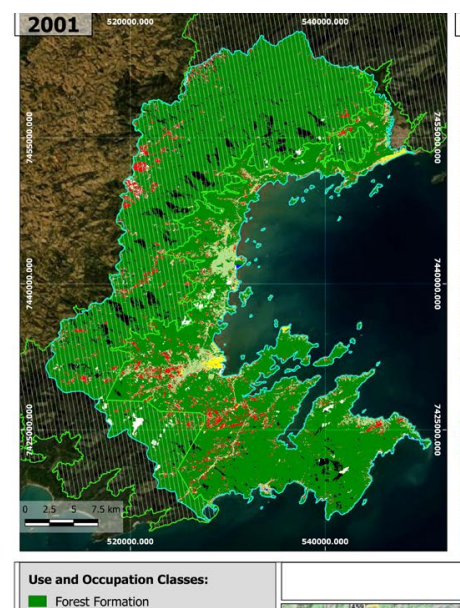

Forest Formation
Sea / Ocean

Constructed Are

- Shade

- Claud

Exposed Soil / Pasture

Ground Vegetation

Caption:

Paraty - Rio de Janeiro (Brazil)

Serra da Bocaina National Park

Subject: Anthropic expansion analysis in the of Paraty in relation to the Seri da Bocaina Nare
Forest Biome).

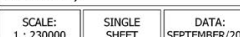

Source: The authors, 2020 .

Table 1 - Values of areas, in square kilometers and percentage, corresponding to each land use and land occupation class in Paraty, in 2001, 2006, and 2018

\begin{tabular}{lcccccc}
\hline $\begin{array}{l}\text { Land use and occu- } \\
\text { pation }\end{array}$ & \multicolumn{2}{c}{2001} & \multicolumn{3}{c}{2006} \\
& $\begin{array}{c}\text { Area } \\
\mathbf{( \mathbf { k m } ^ { 2 } )}\end{array}$ & Area $\mathbf{( \% )}$ & $\begin{array}{c}\text { Area } \\
\mathbf{( \mathbf { k m } ^ { 2 } )}\end{array}$ & Área (\%) & $\begin{array}{c}\text { Área } \\
\left.\mathbf{( k m}^{2}\right)\end{array}$ & Área (\%) \\
\hline Forest Formation & 793.62 & 85.76 & 755.93 & 81,69 & 706,45 & 76,34 \\
Constructed area & 4.82 & 0.52 & 5.52 & 0,60 & 6,07 & 0,66 \\
$\begin{array}{l}\text { River, lake, and } \\
\text { ocean }\end{array}$ & 6.17 & 0.67 & 16.74 & 1,81 & 11,86 & 1,28 \\
$\begin{array}{l}\text { Pasture and exposed } \\
\text { soil }\end{array}$ & 25.51 & 2.76 & 25.14 & 2,72 & 27,92 & 3,02 \\
$\begin{array}{l}\text { Ground vegetation } \\
\text { Shade }\end{array}$ & 64.64 & 6.99 & 62.34 & 6,74 & 78,71 & 8,51 \\
\hline Total & 117.79 & 12.73 & 59.72 & 6,45 & 7,22 & 0,78 \\
\hline
\end{tabular}

Source: The authors, 2020. 
In 2006, based on values from 2001, there was an increase of about 0.33 square kilometers of constructed and pasture areas $(\sim 1.09 \%)$. While in 2018, these same areas increased by about 3.66 square kilometers ( $12.07 \%$, compared to 2001). Moreover, concerning forest formation, one can notice a significant reduction in its coverage area over time, which is evidenced in Figure 1. Analyzing the data in Table 1, it is shown that there was a reduction of 8.59 square kilometers of this area (about 1.05\%) in 2006, while in 2018 this reduction was 23.40 square kilometers (about 2.84\%), both with respect to values of 2001.

It is worth mentioning that part of the territory where the PNSB was inserted was once considered caiçara, quilombola, and indigenous lands - communities that use the forest in an extractive manner to maintain their existence. It is clear that a dialogue between these traditional communities and the park management is necessary for land regularization of occupied areas. However, according to the SNUC, urban agglomerations are not allowed in fully protected areas, and thus, this population must be removed to areas outside park boundaries. What is being discussed, not only concerning the PNSB but for most Brazilian national parks, is that this population was occupying these areas before park demarcation, making this process more complex. It can be assessed that the form adopted by the Brazilian legislation for park (and other fully protected areas) establishment, which is exclusionary for traditional communities, must be widely discussed with local populations and governments, so the rights of traditional groups could be taken into account.

What occurs, according to Abirached (2011), is that there is real estate pressure on the lands of these traditional communities that are shrouded by the public agencies in face of the municipal development.

The issue involving territorial development, which here we take the liberty to declare, is unsustainable; because, according to Egerl, De Gusmão, and Santos (2013), it is socially exclusive and does not reliably cover environmental policies, and it can be assumed that there are ways to circumvent these laws, focusing only on economic issues that do not involve these communities, but only interests of large corporations.

It is important to note the inefficiency of the State's governance in face of the decision-making processes with relation to urban planning. However, it is necessary to make it clear that this is a turbulent historical process between different federative levels that lacks proper dialogue and commitment with the problems involving local communities, because it excludes the debate, when it exists, over developmental issues of the municipalities.

The observed is a diffuse increase in anthropic occupation, disrespecting the municipal planning and park management plan, and going toward norms established by environmental management agencies. This is reflected in the reduction of native vegetation both in park designated areas and in its buffer zone, compromising local fauna and flora preservation. 


\section{Final considerations}

The municipal and environmental agencies must strive for joint improvements to the management of either the municipality of Paraty and the PNSB, especially concerning the dynamics of use and occupation in these two areas. This includes stimuli for norm reformulations since the evident disagreement between Master and Management Plans, along with incentives for norm enforcement and conscientization public policies for the population of Paraty.

A plausible solution would be the elaboration of the Environment and Natural Resources Management Plan, as stipulated in the Master Plan, and its adjustment to the reality of both the municipality and the PNSB, so that it encompasses all points addressed in this work and fulfills its original objectives, ensuring the protection of municipal environmental and cultural heritage. The aforementioned Management Plan could also address the use and occupation issues within Park surroundings, encouraging local non-intensive agriculture to reduce the impacts of this type of activity on biodiversity, as suggested by Palomo et al. (2014).

Furthermore, there is the issue about the SNUC's rigidity regarding the communities that inhabit National Parks designated areas. In some cases, these communities existed long before park creation, and since SNUC was established (BRASIL, 2000), they are subjected to regulations on its Management Plan, often imposing harsh conducts, with no respect to already existing affective and cultural ties, nor to ongoing conservative works, some communities use to carry out. It is of utmost necessity that the Management Plan takes into consideration the reality of these communities, to preserve their identity and, at the same time, to ensure they contribute to the maintenance and conservation of local biodiversity.

\section{Acknowledgments}

The authors thanks the "Coordenação de Aperfeiçoamento do Pessoal de Nível Superior" (CAPES) and the "Fundação de Amparo à Pesquisa de Minas Gerais" (FAPEMIG) for scholarships provided and the environmental analyst Andreia Q. Monteiro (PNSB/ ICMBio) for the dedicated attention. 


\section{References}

ABIRACHED, Carlos Felipe de Andrade. Ordenamento territorial e áreas protegidas: conflitos entre instrumentos e direitos de populações tradicionais de Ubatuba-Paraty. 2011. 178 f. Dissertação de mestrado em Desenvolvimento Sustentável (Centro de Desenvolvimento Sustentável da Universidade de Brasília). Brasília, 2011. Disponível em: < https://repositorio.unb.br/handle/10482/9568 > . Acesso em: ago. 2020.

BARBOSA, G. B.; OLIVEIRA, F. A. D.; RIBEIRO, P. R. D. Zoneamento urbano e direito fundamental ao trabalho: possibilidades para o desenvolvimento sustentável. Planeta Amazônia: Revista Internacional de Direito Ambiental e Políticas Públicas, Macapá, [s. v.], n. 8, p. 181-190. 2016. Disponível em: https://periodicos.unifap.br/index.php/planeta/article/view/3017. Acessoem: 01 out. 2018.

BERNARD, E.; PENNA, L. A. O.; ARAÚJO, E. Downgrading, downsizing, degazettment, and reclassification of Protected Areas in Brazil. Conservation Biology, Washington, v. 28, n. 4, p. 939-950, jan. 2014. Disponívelem: https://onlinelibrary.wiley.com/doi/abs/10.1111/cobi.12298. Acesso em: 17 nov. 2018.

BRASIL. Constituição da República Federativa do Brasil de 1988. Disponível em: http://www. planalto.gov.br/ccivil_03/constituicao/constituicaocompilado.htm. Acesso em: 09 out. 2018.

. Decreto no 4.340, de 22 de agosto de 2002. Regulamenta artigos da Lei no 9.985, de 18 de julho de 2000, que dispõe sobre o Sistema Nacional de Unidades de Conservação da Natureza - SNUC, e dá outras providências. Disponível em: http://www.planalto.gov.br/ccivil_03/decreto/2002/D4340.htm. Acesso em: 09 out. 2018.

. Decreto no 5.746, de 5 de abril de 2006. Regulamenta o art. 21 da Lei no 9.985, de 18 de julho de 2000, que dispõe sobre o Sistema Nacional de Unidades de Conservação da Natureza. Disponível em: http://www.planalto.gov.br/ccivil_03/_Ato2004-2006/2006/Decreto/D5746.htm. Acesso em: 09 out. 2018.

. Decreto no 68.172, de 4 de fevereiro de 1971. Cria o Parque Nacional da Serra da Bocaina e dá outras providências. Disponível em: http://www.planalto.gov.br/ccivil_03/decreto/1970-1979/D68172.htm. Acesso em: 09 out. 2018.

. Lei no 9.985, de 18 de julho de 2000. Regulamenta o art. 225, § 1o, incisos I, II, III e VII da Constituição Federal, institui o Sistema Nacional de Unidades de Conservação da Natureza e dá outras providências. Disponível em: http://www.planalto.gov.br/ccivil_03/leis/19985.htm. Acesso em: 09 out. 2018.

. Lei n⿳⺈ 10.257, de 10 de julho de 2001. Regulamenta os arts. 182 e 183 da Constituição Federal, estabelece diretrizes gerais da política urbana e dá outras providências. Disponível em: http://www.planalto.gov.br/ccivil_03/leis/LEIS_2001/L10257.htm. Acesso em: 09 out. 2018.

. Lei n⿳⺈ 12.608, de 10 de abril de 2012. Institui a Política Nacional de Proteção e Defesa Civil; dispõe sobre o Sistema Nacional de Proteção e Defesa Civil e o Conselho Nacional de Proteção e Defesa Civil; autoriza a criação de sistema de informações e monitoramento de desas- 
tres, e dá outras providências. Disponível em: http:/www.planalto.gov.br/ccivil_03/_Ato20112014/2012/Lei/L12608.htm. Acesso em: 09 out. 2018.

BRITO, D. M. C. Conflitos em Unidades de Conservação. Revista PRACS, Macapá, v. 1, n. 1, p. 1-12, dez. 2008. Disponível em: https://periodicos.unifap.br/index.php/pracs/article/view/10. Acesso em: 09 out. 2018.

CLIMATE-DATE. Clima: Paraty. Disponível em: https://pt.climate-data.org/america-do-sul/ brasil/rio-de-janeiro/paraty-15848/. Acesso em: 01 out. 2018.

COAD, L.; LEVERINGTON, F; KNIGHTS, K.; GELDMANN, J.; EASSOM, A.; KAPOS, V. et al. Measuring impact of protected area management interventions: current and future use of the Global Database of Protected Area Management Effectiveness.Philosophical Transactions of the Royal Society B, London, v. 370, [s. n.], p. 1-10, oct. 2015.Disponível em: http://rstb.royalsocietypublishing.org/content/370/1681/20140281. Acesso em: 16 nov. 2018.

CUMMING, G. S.; AllEN, C. R.; BAN, N. C.; BIGGS, D.; BIGGS, H. C.; CUMMING, D. H. M. et al. Understanding protected area resilience: a multi-scale, social-ecological approach. EcologicalApplications, Washington, v. 25, n. 2, p. 299-319, mar. 2015. Disponível em: https:// esajournals.onlinelibrary.wiley.com/doi/abs/10.1890/13-2113.1. Acesso em: 16 nov. 2018.

EGLER, Cláudio Antônio Gonçalves; DE GUSMÃO, Paulo Pereira; SANTOS, Bianca Borges Medeiros. ST2-635 Governança e desenvolvimento territorial: uma visão a partir da zona costeira do sudeste brasileiro. Anais ENANPUR, v. 15, n. 1, 2013. Disponível em: < http:/www.anpur. org.br/ojs/index.php/anaisenanpur/article/view/133/130>. Acesso em: ago. 2020.

FIGUEIROA, A. C.; SCHERER, M. E. Para onde estamos indo? Uma avaliação do Plano Diretor do Município de Florianópolis para o entorno da Estação Ecológica de Carijós. Desenvolvimento e Meio Ambiente, v. 38, [s. n.], p. 283-301, ago. 2016. Disponível em: https://revistas.ufpr.br/ made/article/view/47110. Acesso em: 09 out. 2018.

FONTES, C. F. L.; GUERRA, A. J. T. Conflitos socioambientais na APA de Cairuçu (Paraty-RJ) à luz da sobreposição com unidades de conservação de diferentes categorias. GEOUSP (Online), São Paulo, v. 20, n. 1, p. 178-193, jan./abr. 2016. Disponível em: http://www.revistas.usp.br/ geousp/article/view/85275. Acesso em: 09 out. 2018.

FREITAS, D. A. et al. Levantamento de dados de espécies florestais nativas do Cerrado: um meio para bancos de sementes implantados que permitem restauração e conservação de ecossistemas florestais. Brazilian Journal of Animal and Environmental Research, v. 2, n. 5, p. 1569-1583, 2019.

GARCIA, L. V. M.; MILAN, E.; ANTUNES, D. A.; MORO, R. S. Plano de Manejo da Floresta Nacional de Caxiuanã (PA): conflitos entre interesses de populações tradicionais e unidades de conservação. Terr@Plural, Ponta Grossa, v. 8, n. 2, p. 355-369, jul./dez. 2014. Disponível em: http://www.revistas2.uepg.br/index.php/tp/article/view/7658. Acessoem: 09 out. 2018.

GELDMANN, J.; COAD, L.; BARNES, M.; CRAIGIE, I. D.; HOCKINGS, M.; KNIGHTS, K.et al. Changes in protected area management effectiveness over time: a global analysis. Biological- 
Conservation, Amsterdam, v. 191, p. 692-699, sep. 2015. Disponível em: https://www.sciencedirect.com/science/article/abs/pii/S0006320715300793. Acesso em: 16 nov. 2018.

GOUNARIDIS, D.; APOSTOLOU, A.; KOUKOULAS, S. Land cover of Greece, 2010: a semi-automatic classification using random forests. Journal of Maps, London, v. 12, n. 5, p. 1055 1062, 2016. Disponívelem: https://www.tandfonline.com/doi/full/10.1080/17445647.2015.1123 656. Acesso em: 15 nov. 2018.

GOUNARIDIS, D.; APOSTOLOU, A.; RIGA, M.; MOUSTOS, P.; BIKA, K.; KONTOU, D. et al. Change detection of forests and semi-natural areas in Greece for the period 1990-2010. AEgean Journal of Environmental Sciences, Lesvos, v. 2, [s. n.], p. 1-10, 2016. Disponível em: http:// www.env.aegean.gr/wp-content/uploads/2017/03/Gounaridis-et-al_AEJES_2016.pdf. Acessoem: 15 nov. 2018.

GRAY, C. L.; HILL, S. L. L.; NEWBOLD, T.; HUDSON, L. N.; BÖRGER, L.; CONTU, S. et al. Local biodiversity is higher inside than outside terrestrial protected areas worldwide. Nature Communications, London, v. 7, [s. n.], p. 1-7, jul. 2016. Disponível em: https://www.nature.com/ articles/ncomms12306. Acesso em: 16 nov. 2018.

HANSEN, A. J.; DEFRIES, R. Ecological mechanisms linking Protected Areas to surrounding lands. EcologicalApplications, Washington, v. 17, n. 4, p. 974-988, jun. 2007. Disponível em: https://esajournals.onlinelibrary.wiley.com/doi/10.1890/05-1098\#. Acesso em: 14 nov. 2018.

IBGE. Instituto Brasileiro de Geografia e Estatística. Município de Paraty: Panorama. 2010.Disponível em: https://cidades.ibge.gov.br/brasil/rj/paraty/panorama. Acesso em: 20 set. 2018.

ICMBio. Instituto Chico Mendes de Conservação da Biodiversidade. Instrução Normativa n⿳o 3, de 1 de setembro de 2014. Fixa normas para a utilização do Sistema de Autorização e Informação em Biodiversidade - SISBio, e regulamenta a disponibilização, o acesso e o uso de dados e informações. Disponível em: http://www.lex.com.br/legis_25911025_INSTRUCAO_ NORMATIVA_N_3_DE_1_DE_SETEMBRO_DE_2014.aspx. Acesso em: 09 out. 2018.

. Instituto Chico Mendes de Conservação da Biodiversidade.Plano de Manejo do Parque Nacional Serra da Bocaina.São José do Barreiro, São Paulo, 2001.Disponível em: https://www. icmbio.gov.br/portal/images/stories/imgs-unidades-coservacao/Parte_1. Acesso em: 01 out. 2018.

- Instituto Chico Mendes de Conservação da Biodiversidade. Portaria Ibama no 112 , de 21 de agosto de 2002. Aprova o Plano de Manejo do Parque Nacional da Serra da Bocaina. Disponível em: https://www.icmbio.gov.br/parnaserradabocaina/images/stories/plano_de_manejo/ Portaria_Plano_de_\%20Manejo_\%20Bocaina.pdfAcesso em: 09 out. 2018.

JACINTHO, L. R. C. Geoprocessamento e sensoriamento remoto como ferramenta na gestão ambiental de unidades de conservação: $O$ caso da Área de Proteção Ambiental (APA) do Capivari-Monos, São Paulo-SP. 2003. Dissertação (Mestrado em Recursos Minerais e Hidrogeologia) \Universidade de São Paulo, São Paulo, 2003. Disponível em:http://www.teses.usp.br/teses/disponiveis/44/44133/tde-14082003-230137/pt-br.php. Acesso em: 27 out. 2018.

KAIN, J.; LARONDELLE, N.; HAASE, D.; KACZOROWSKA, A. Exploring local consequen- 
ces of two land-use alternatives for the supply of urban ecosystem services in Stockholm year 2050. Ecological Indicators, v. 60, p. 38-44, jan. 2016. Acessoem: 23 out. 2018.

KLINK, C. A.; MACHADO, R. B. A conservação do Cerrado brasileiro. Megadiversidade, v. 1, n. 1, p. 147-155, 2005.

KOCH, A. H. S. Zona de amortecimento da Floresta Nacional de São Francisco de Paula: alterações da cobertura do solo. Revista Metropolitana de Sustentabilidade, São Paulo, v. 6, n. 3, p. 123-139, set./dez., 2016. Disponível em: www.revistaseletronicas.fmu.br/index.php/rms/article/ view/913. Acessoem: 09 out. 2018.

MARANDOLA JUNIOR, Cesar Marques; DE PAULA, Luiz Tiago; CASSANELI, Letícia Braga. Crescimento urbano e áreas de risco no litoral norte do Estado de São Paulo. Rev. Bras. Estud. Popul., vol. 30, n. 01, 2013. São Paulo. Disponível em: < https://doi.org/10.1590/S0102$30982013000100003>$. Acesso em: ago. 2020.

MAS, J. F; LEMOINE-RODRÍGUEZ, R.; GONZÁLEZ-LÓPEZ, R.; LÓPEZ-SÁNCHEZ, J.; PIÑA-GARDUÑO, A.; HERRERA-FLORES, E. Land use/land cover change detection combining automatic processing and visual interpretation. European Journal of Remote Sensing, London, v. 50, n. 1, p. 626-635, oct. 2017. Disponível em: https://www.tandfonline.com/doi/full/10.1 080/22797254.2017.1387505. Acesso em: 15 nov. 2018.

MELO, I. S.; SILVA, D. B.; SANTOS, A. L. A.; SANTANA, F. S.; SANTANA B. L. P. Atividades antrópicas e degradação ambiental na sub-bacia hidrográfica do Rio Itamirim-SE. Revista de Geociências do Nordeste, Caicó, v. 2, [s. n.], p. 435-442, out. 2016. Disponível em: https:// periodicos.ufrn.br/revistadoregne/article/view/10485. Acesso em: 09 out. 2018.

MYERS, N.; MITTERMEIER, R. A.; MITTERMEIER, C. G.; FONSECA, G. A. B.; KENT, J. Biodiversity hotspots for conservation priorities. Nature, v. 403 p. 853-858, 2000.

NOVAES, D. M.; SILVA, L. R.; GOUVEIA, G. P.;FURQUIM, F. S. Plano operativo de prevenção e combate aos incêndios florestais do Parque Nacional da Serra da Bocaina-RJ. São José do Barreiro: Instituto Brasileiro do Meio Ambiente e Recursos Naturais Renováveis- Ibama, 2005. 25 p. Disponível em: https://www.ibama.gov.br/phocadownload/prevfogo/planos_operativos/39. -parque_nacional_serra_bocaina-rj.pdf. Acesso em: 01 out. 2018.

OLIVEIRA, R. C. M.; LIMA, P. V. P. S.; SOUSA, R. P. Gestão ambiental e gestão dos recursos hídricos no contexto do uso e ocupação do solo nos municípios. Gestão \& Regionalidade, São Caetano do Sul, v. 33, n. 97, p. 49-64, 2017. Disponível em: http://seer.uscs.edu.br/index.php/ revista_gestao/article/view/3101/2099. Acessoem: 29 set. 2018.

PAGLIA, A. P.; FONSECA, G. A. B.; RYLANDS, A. B.; HERRMANN, G.; AGUIAR, L. M. S.; CHIARELLO, A. G.; LEITE, Y. L. R.; COSTA, L. P.; SICILIANO, S.; KIERULFF, M. C. M.; MENDES, S. L.; TAVARES, V. C.; MITTERMEIER, R. A.; PATTON, J. L. Lista anotada dos mamíferos do Brasil. 2. ed. Occasional Papers in Conservation Biology, v. 6, p. 1-76, 2012. Acessoem: 12 nov. 2018. 
PALOMO, I.; MARTÍN-LÓPEZ, B.; ZORRILLA-MIRAS, P.; AMO, D. G. D.; MONTES, C. Deliberative mapping of ecosystem services within and around Doñana National Park (SW Spain) in relation to land use change. Regional Environmental Change, New York, v. 14, n. 1, p. 237 251, feb. 2014. Disponível em: https:/link.springer.com/article/10.1007/s10113-013-0488-5. Acesso em: 17 nov. 2018.

PINTO, L. V. A.; ROMA, T. N.; BALIEIRO, K. R. C. Avaliação qualitativa da água de nascentes com diferentes com diferentes usos do solo em seu entorno. Cerne, Lavras, v. 18, n. 3, p. 495-505, jul./set. 2012. Disponível em: http://www.scielo.br/scielo.php?pid=S0104$-77602012000300018 \&$ script=sci_abstract\&tlng=pt. Acesso em: 12 nov. 2018.

PRATES, C. J. N.; BARBOSA, R. P.; FOGAÇA, J. J. N. L.; LEMOS, O. L.; DUTRA, F. V.; SILVA, R. M. Análise multitemporal de uso e ocupação do solo com enfoque na silvicultura no município de Cândido Sales, Bahia, nos anos de 2005 e 2015. Anuário do Instituto de Geociências, Rio de Janeiro, v. 40, n. 1, p. 150-155, jan. 2017. Disponível em: https://revistas.ufrj.br/index. php/aigeo/article/view/18236. Acesso em: 01 nov. 2018.

RIO DE JANEIRO. Lei complementar no 034, de 9 de janeiro de 2007. Institui o Plano Diretor de Desenvolvimento Integrado do Município de Paraty. Disponível em: http://www.paraty.rj.gov. br/camaraparaty/painel/Leis/_034_2007.pdf. Acesso em: 20 set. 2018.

. Lei Orgânica de Paraty, de 5 de abril de 1990. Disponível em: http://www.sepexrio. org.br/wp-content /2013/03/lei_organica_paraty_05041990.pdf. Acesso em: 17 out. 2018.

ROCHA, L. G. M. da; DRUMMOND, José Augusto; GANEM, Roseli Senna. Parques Nacionais brasileiros: problemas fundiários e alternativas para a sua resolução. Revista de Sociologia e Política, [S.1.], v. 18, n. 36, jun. 2010. Disponível em: < https://revistas.ufpr.br/rsp/article/ view/31639>. Acesso em: 15 jan. 2019.

RUDKE, A. P.; BRITO, A. C. C.; CARREIRA, J. C.; BEZERRA, R. R.; SANTOS, A. M. Análise multitemporal da cobertura vegetal na reserva biológica do Jaru e zona de amortecimento, Rondônia. In: XVI SIMPÓSIO BRASILEIRO DE SENSORIAMENTO REMOTO, 2013, Foz do Iguaçu. Anais... São José dos Campos: INPE, 2013. Disponível em: http://marte2.sid.inpe.br/ col/dpi.inpe.br/marte2/2013/05.29.01.05.08/doc/p1625.pdf. Acesso em: 09 out. 2018.

RUIZ JUNIOR, Luiz Donizetti; DE OLIVEIRA, Regina Celia. Áreas protegidas e expansão do uso da terra no litoral norte do estado de São Paulo. Caminhos de Geografia, v. 14, n. 48, 2013. Disponível em: <http://www.seer.ufu.br/index.php/caminhosdegeografia/article/view/23764>. Acesso em: ago. 2020.

SANTOS, R. P.; PACHECO, C. S. G. R. A ação antrópica e suas implicações na cobertura vegetal da comunidade rural de Paredão/BA: estudo comparativo de áreas intactas e degradadas. Revista Semiárido de Visu, Petrolina, v. 5, n. 1, p. 45-51, jan./abr. 2017. Disponível em: https:// periodicos.ifsertao-pe.edu.br/ojs2/index.php/revista/article/view/362. Acesso em: 09 out. 2018.

SILVA, Camilo V. T.; RIBEIRO FILHO, J. C.; SILVA, P. C. M.; LEMOS FILHO, L. C. A.; BRASIL, J. B. Caracterização morfométrica, uso e ocupação de uma bacia hidrográfica. Revista Engenharia na Agricultura, Viçosa, v. 25, n. 5, p. 436-444, nov. 2017. Disponível em: https://periodi- 
cos.ufv.br/reveng/article/view/740. Acesso em: 01 nov. 2018.

SILVA, J. L. C.; VIDAL, C. A. S.; BARROS, L. M.; FREITA, F. R. V. Aspectos da degradação ambiental no Nordeste do Brasil. Revista Gestão \& Sustentabilidade Ambiental, Florianópolis, v. 7, n. 2, p. 180-191, abr./jun. 2018. Disponível em: http://www.portaldeperiodicos.unisul.br/index. php/gestao_ambiental/article/view/6206. Acesso em: 09 out. 2018.

SILVA, J. S.; SILVA, R. M.; SILVA, A. M. Mudanças do uso e ocupação do solo e degradação eco-ambiental usando imagens orbitais: o estudo de caso da bacia do Rio Bacanga, São Luís (MA). Revista Brasileira de Geografia Física, Recife, v. 9, n. 1, p. 265-279, jan. 2016. Disponível em: https://periodicos.ufpe.br/revistas/rbgfe/article/view/233518. Acesso em: 01 out. 2018.

SILVA, Matheus M.; SANTOS, I. F.; SILVA, F. R. C.; TEIXEIRA, C. P. Unidades de Conservação e comunidades locais: gestão de conflitos e instrumentos de participação. Revista Estudo \& Debate, Lajeado, v. 24, n. 3, p. 208-218, out. 2017. Disponível em: http://www.univates.br/ revistas/index.php/estudoedebate/article/viewFile/1397/1247. Acesso em: 09 out. 2018.

SILVA, O. C. A. Análise da suscetibilidade a escorregamentos e as implicações da evolução do uso e cobertura do solo no município de Paraty, RJ, entre 1973 e 2008. 2010. 151 f. Dissertação (Mestrado em Hidrogeologia e Meio Ambiente) $\square$ Universidade de São Paulo, São Paulo, 2010. Disponível em: http://www.teses.usp.br/teses/disponiveis/44/44138/tde-06052010-105556/pt-br. php. Acesso em: 27 out. 2018.

SILVA, S. M. Mata Atlântica: uma apresentação.In: Revisões em zoologia: Mata Atlântica. 1. ed. Curitiba: Ed. UFPR, 490 p. 2017. Acesso em: 12 nov. 2018.

SOUSA, E. N. C.; SANTOS, F. A. O processo de implantação do Parque Estadual do Cocó, Fortaleza (CE): conflitos e perspectivas. Revista de Geociências do Nordeste, Caicó, v. 2, p. 781-790, out. 2016. Disponível em: https://periodicos.ufrn.br/revistadoregne/article/view/10526. Acesso em: 09 out. 2018.

VALE, J. R. B.; COSTA, J. A.; SANTOS, J. F.; SILVA, E. L. S.; FAVACHO, A. T. Análise comparativa de métodos de classificação supervisionada aplicada ao mapeamento da cobertura do solo no município de Medicilândia, Pará. Interespaço: Revista de Geografia e Interdisciplinaridade, Grajaú, v. 4, n. 13, p. 26-44, jan./abr. 2018. Disponível em: http://www.periodicoseletronicos. ufma.br/index.php/interespaco/article/view/7884. Acessoem: 01 nov. 2018.

WATSON, F. G. R.; BECKER, M. S.; MILANZI, J.; NYIRENDA, M. Human encroachment into protected area networks in Zambia: implications for large carnivore conservation. Regional Environmental Change, New York, v. 15, n. 2, p. 415-429, feb. 2015. Disponível em: https://link. springer.com/article/10.1007/s10113-014-0629-5. Acesso em: 17 nov. 2018.

WILLIS, K. S. Remote sensing change detection for ecological monitoring in United States protected areas. BiologicalConservation, Amsterdam, v. 182, [s. n.], p. 233-242, feb. 2015. Disponível em: https://www.sciencedirect.com/science/article/abs/pii/S0006320714004790. Acesso em: 17 nov. 2018. 


\section{Camila Coelho Welerson}

$\checkmark$ camila.welerson@gmail.com

ORCiD: ttps://orcid.org/0000-0002-9557-6111
Submitted on: $17 / 12 / 2020$

Accepted on: 22/12/2020

2021;24e:00231

\section{Winne Nayadini Barão}

$\checkmark$ winne_nayadini@hotmail.com

ORCiD: https://orcid.org/0000-0001-7129-5924

\section{Brunna Araújo Quireli}

$\varangle$ bruaraujoquireli@gmail.com

ORCiD: https://orcid.org/0000-0003-0697-4511

\section{Vanêssa Lopes de Faria}

$\checkmark$ vanessasgp@yahoo.com.br

ORCiD: https://orcid.org/0000-0002-9113-7808

\section{Daniela Rocha Teixeira Riondet-Costa}

$\varangle$ danielart@unifei.edu.br

ORCiD: orcid.org/0000-0001-9355-6056

\section{Nívea Adriana Dias Pons}

$\varangle$ niveadpons@gmail.com

ORCiD: http://orcid.org/0000-0002-6997-6576

\section{Ana Luíza de Souza Marcondes}

$\checkmark$ analuiza.marcondes@outlook.com

ORCiD: https://orcid.org/0000-0002-2898-086X

How to cite: WELERSON, C. C.; BARÃO, W. N; QUIRELI, B. A.; FARIA, V. L.; RIONDET-COSTA, D. R. T.; PONS, N. A. D.; MARCONDES, A. L. S. Anthropic expansion of Paraty in Serra da Bocaina National Park, Mata Atlântica Biome. Ambiente \& Sociedade. São Paulo, v. 24, p. 1-18, 2021. 


\title{
Expansão antrópica de Paraty no Parque Nacional Serra da Bocaina, Bioma Mata Atlântica
}

\author{
Camila Coelho Welerson \\ Winne Nayadini Barão \\ Brunna Araújo Quireli \\ Vanêssa Lopes de Faria \\ Nivea Adriana Dias Pons \\ Daniela Rocha Teixeira Riondet-Costa \\ Ana Luiza de Souza Marcondes
}

São Paulo. Vol. 24, 2021

Artigo Original
Resumo: Este trabalho analisou a expansão antrópica do município de Paraty-RJ em relação ao Parque Nacional da Serra da Bocaina. Além da revisão bibliográfica e documental do Plano Diretor do município e do Plano de Manejo do Parque, usou-se ferramentas de geoprocessamento para análises cronológicas de alteração de uso e ocupação do solo nos anos de 2001, 2006 e 2018, utilizando-se imagens do satélite Landsat 5 e Landsat 8. Verificou-se o crescimento da ocupação antrópica de maneira difusa em relação ao Parque, sem respeito ao planejamento municipal, refletindo na diminuição da cobertura vegetal nativa. Concluiu-se que ambos os Planos Diretor e de Manejo têm se mostrado ineficientes quanto aos seus objetivos, justificando a necessidade de melhorias na gestão de Paraty e do Parque por meio dos órgãos responsáveis.

Palavras-chave: Áreas protegidas; uso do solo; geoprocessamento; ocupação irregular; gestão ambiental.

Como citar: WELERSON, C. C.; BARÃO, W. N; QUIRELI, B. A.; FARIA, V. L.; RIONDET-COSTA, D. R. T.; PONS, N. A. D.; MARCONDES, A. L. S. Expansão antrópica de Paraty no Parque Nacional Serra da Bocaina, Bioma Mata Atlântica. Ambiente $\mathbb{\&}$ Sociedade. São Paulo, v. 24, p. 1-18, 2021. 


\title{
Expansión antropogénica de Paraty en el Parque Nacional Serra da Bocaina, Bioma Mata Atlântica
}

\author{
Camila Coelho Welerson \\ Winne Nayadini Barão \\ Brunna Araújo Quireli \\ Vanêssa Lopes de Faria \\ Nivea Adriana Dias Pons \\ Daniela Rocha Teixeira Riondet-Costa \\ Ana Luiza de Souza Marcondes
}

São Paulo. Vol. 24, 2021

Artículo original
Resumen: Se analizó la expansión antrópica del municipio de Paraty-RJ en relación con el Parque Nacional Serra da Bocaina. Además de la revisión bibliográfica y documental del Plan Maestro Municipal y el Plan de Gestión del Parque, se utilizaron herramientas de geoprocesamiento para los análisis cronológicos del uso del suelo y el cambio de ocupación en 2001, 2006 y 2018, utilizando imágenes del satélite Landsat 5 y Landsat 8. Hubo un aumento de la ocupación humana hacia el Parque, sin tener en cuenta la planificación municipal, lo que se refleja en la disminución de la cubierta vegetal nativa. Ambos planes han sido ineficientes en sus objetivos, y se necesitan mejoras en la gestión de Paraty y Park a través de las agencias responsables.

Palabras-clave: Uso de la tierra; área protegida; geoprocesamiento; ocupación irregular; gestión ambiental.

Como citar: WELERSON, C. C.; BARÃO, W. N; QUIRELI, B. A.; FARIA, V. L.; RIONDET-COSTA, D. R. T.; PONS, N. A. D.; MARCONDES, A. L. S. Expansión antropogénica de Paraty em el Parque Nacional Serra da Bocaina, Bioma Mata Atlântica. Ambiente $\&$ Sociedade. São Paulo, v. 24, p. 1-18, 2021.

DOI: http://dx.doi.org/10.1590/1809-4422asoc20200023r1vu2021L2AO 